\title{
Social Media, Confusion, and Small Business During the COVID 19 Crisis
}

\author{
Daniel Sullivan \\ Ashland University \\ Daniel Fox \\ Ashland University \\ Robert Stoll \\ Ashland University \\ Raymond Jacobs \\ Ashland University
}

In March 2020, the U.S. economy began a systematic shutdown in response to the COVID 19 pandemic. Schools, churches, retail, and service business all closed as states implemented stay at home orders in the name of public safety. Business fell into either essential or non-essential classifications in response to state and local government mandates. Loosely worded guideline created confusion among small business owners and their customers as to what services were available. This study examines the confused state of small business in response to their classification and the methods used by business owners to communicate their status to customers.

Keywords: small business, social media, COVID 19

\section{INTRODUCTION}

The COVID 19 pandemic has devastated the American economy (Stangler, 2020) and its 30.2 million small businesses (Giese, 2020). According to the NFIB Study on the Impact of COVID-19 on Small Business, seventy six percent of small businesses have been negatively impacted by the COVID 19 crisis (NFIB, 23 March, 2020) as of mid-March. This impact increased to $92 \%$ by the end of March 2020 (NFIB, 2 April 2020). In early May 2020, over 22 million U.S. jobs had been lost due to the pandemic with most of the losses occurring in small business (Coleman, 2020). Some experts believe that small business losses could exceed one trillion dollars before the crisis ends (Ritholtz, 2020).

In the face of this historic crisis, many small business owners struggled with the confusion over essential verses non-essential business classifications issued by state governments. Small business owners also faced challenges with finding ways to communicate their status to customers throughout the crisis. Many small businesses classified as essential managed to remain open during the crisis. The essential classification increased survival rates for many small business owners (Conerly, 2020). Small businesses, deemed non- 
essential, shut down following their state's shelter in place orders, essentially closing from mid-March to mid-May 2020. As a result, business owners operating non-essential businesses viewed the COVID 19 pandemic as a battle for survival (Twiste, 2020). This study assesses the response of small business owners to the pandemic. It assesses how business in a small Midwestern city coped with the state government's classification process. This study also assesses the communication techniques used by small business owners to convey their status during the shelter-in place shutdown period as well as techniques used to communicate their reopening status.

\section{LITERATURE REVIEW}

Prior to the COVID 19 pandemic, small businesses contribute 44\% of the Gross Domestic Product (GDP) each year (Dore, 2019). Experts predict that once final calculation are completed, small business' 2019 GDP contributions will exceed \$ 9.3 trillion. Small businesses employ an estimated 58.9 million people or approximately $47.5 \%$ of all working Americans (Lauckner, 2020). In a matter of months, small business' contribution to the GDP and employment security is in peril. By mid-March 2020, the US Chamber of Commerce estimated that one in four or approximately 7.6 million small businesses temporarily closed due to the COVID 19 pandemic. U.S. unemployment due to the pandemic exceeded 22 million workers (Long, 2020) by late April with the final number of displaced workers still unknown at this time.

In response to the pandemic, States issued stay at home orders for residents and ordered non-essential businesses to close. Essential business/organizations were defined as are those needed to "maintain heath care, public health operations, human service operations, essential government functions, and essential infrastructure" (Acton, 2020). These broad instructions translated into the following partial list of business services deemed essential for example by the State of Ohio (TABLE 1).

TABLE 1

SMALL BUSINESS SERVICES DEEMED ESSENTIAL (OHIO EXAMPLE)

\begin{tabular}{|l|}
\hline \multicolumn{1}{|c|}{ Essential Services } \\
\hline Stores selling Groceries and medicine \\
\hline Food, beverage, agriculture, and licensed marijuana production \\
\hline Organizations that provide charitable and social services \\
\hline Gas stations and businesses needed for transportation \\
\hline Financial and insurance institutions \\
\hline Hardware and supply stores \\
\hline Critical trades \\
\hline Mail, post, shipping, logistics, delivery, and pick up services \\
\hline Restaurants for consumption off-premises \\
\hline Supplies to work from home \\
\hline Laundry services \\
\hline Supplies essential to business operations \\
\hline Transportation services \\
\hline Home care and services \\
\hline Professional services \\
\hline Residential facilities \\
\hline Manufacture, distribution, and supply of critical products and industries \\
\hline Hotels and motels \\
\hline Funeral services \\
\hline
\end{tabular}

Small businesses not falling into the above categories were classified as non-essential. Non-essential businesses were required to close until their State issued a reopening order. As a result, non-essential small 
businesses were hit hardest by the pandemic (Huddleston, 2020). Confusion over these vague classifications prompted small business owners to seek clarification over their status. For example, on just one day in Wisconsin, confusion between essential and non-essential prompted 7,400 calls and online inquiries from small business owners questioning if their business could stay open (Ryan, 2020); a pattern that was repeated across the country (Mack, 2020; Romero, 2020; Sandy 2020). Further, many states left enforcement of the essential/non-essential classification orders to local municipalities resulting is an inconsistent interpretation of the guidelines (Rodriquez, 2020). Compounding the confusion experienced by small businesses was the mixed interpretation of the widely published classifications among customers. Many small businesses owners selling a mixed product line decided to stay open until challenged (Bose \& Fares, 2020).

The COVID 19 pandemic also created a communication crisis for small business owners. Individual business owners were left to their own resources in the manner and timing of their status messages. The effectiveness of face-to-face conversations, a reliable staple the small businesses' communication arsenal (McQuerrey, 2020), was neutralized by governmental stay at home orders. Word-of-mouth messaging failed, as consumers chose to stay in their homes due to safety concerns and embraced online shopping platforms as an alternative (Wahba, 2020). Telephone conversations and voicemail remained an effective technique for small business owners to convey their status during the pandemic. Despite the decreased popularity of this communication media, it still provides business owners with a vehicle for immediate and personal communication (Nestor \& Thompson, 2019).

Another communication technique available to small business was local radio. Experts view radio messaging as an intimate experience for the listener (Marketingcharts, 2019) with many people listening to the radio in solitude. According to Marketingcharts.com, $71 \%$ of people listen to the radio while driving. The appeal of radio advertising to small business owners is a reliance on the habitual nature of customers. Everyone has a favorite radio station they listen to commuting to and from work. Customers usually will program their radios to preset stations accessing them at predetermined times. In addition, many individuals use radio as a way to fill dead spots in their workday. Thus, radio advertising provides small business owners with an effective platform to communicate a message to customers.

Podcasts have emerged as one of the best informational resources for entrepreneurs (Smale, 2010). Podcasts are distributed digital audio files made available to subscribers on the internet for downloading to a computer or mobile device. Similar to radio, podcasts offer small business owners a unique way to connect with customers. Studies show that in 2019, 51\% of the U.S. population ages 14 to 54 listen to podcasts (Peiser, 2019). Companies such as Google, Pandora, Spotify and other continue to build their libraries and create unique advertising opportunities for small businesses (Kaufer, 2020) to communicate with customers. An available but lesser used option for small business communication is television. In many cases, television advertising is limited to small businesses located in areas with access to a local TV station. Small business owners in these markets have the option of advertising through broadcast or cable stations. Rates for television advertising vary by the time slot and programing targeted. A thirty-two second commercial can cost from $\$ 200-\$ 2,000$ to create when using a professional production company (LaMarco, 2019). Though available, the cost of a television spot with undetermined viewership may deter this method of communication in times of economic uncertainty.

Signage is another effective way for small businesses to relate messages to customers. Signs can be as simple as a message written on paper and posted in a visible area or as complex as a post on websites, or email. Signs can convey a traditional static message or convey a flexible and personal meaning depending on the media. For the message contained on the sign to reach the customer, however, the customer must be in close proximity to the sign (for example, standing at the front door of the business).

Social media platforms are increasingly the communication method of choice among customers. The more advanced the delivery platform the more sophisticated the message (Rahman, 2017). According to Statista, 27.2 million or $90 \%$ of U.S. small business use social media platforms to communicate with customers in 2019 (Guttmann, 2019). With 247 million or 79\% of Americans using social media in 2019, digital media platforms provide an effective way for small business to communicate with their customers during times of crisis. 


\section{RESEARCH QUESTION}

This study examines the techniques small business owners used to cope with the essential/non-essential classification imposed by local governments during the COVID 19 pandemic and the communication techniques used to convey business status. The authors posed the following research questions:

1. How did small business owners respond to the essential versus non-essential business classifications imposed by state governments' stay at home orders?

2. What techniques did small business owners employ to communicate their status to customers?

\section{METHODOLOGY}

Researchers at a Midwestern university conducted this study from March 6, 2020 to May 31, 2020. In order to answer the above research questions, fifty-five Midwestern small businesses were survey to assess their response to the COVID 19 crisis. All businesses surveyed were located in a city with a population less than 20,000. The majority of the businesses involved in the study employed less than 10 individuals (TABLE 2).

TABLE 2

NUMBER OF EMPLOYEES IN THE FIRM INCLUDING OWNER

\begin{tabular}{|c|c|}
\hline Number of Employees in the Firm & Number of Businesses in the Study \\
\hline 1 & 16 \\
\hline 2 & 19 \\
\hline 3 & 5 \\
\hline 4 & 5 \\
\hline 5 & 5 \\
\hline 8 & 1 \\
\hline $10+$ & 4 \\
\hline Total & 55 \\
\hline
\end{tabular}

For the purposes of the study, Small businesses were classified as either manufacturing, retail, or service (TABLE 3). These classifications were used to distinguish the nature of the product or service provided by the business.

TABLE 3

TYPES OF SMALL BUSINESSES INVOLVED IN THE STUDY

\begin{tabular}{|c|c|}
\hline Business Classification & Number \\
\hline Manufacturing & 5 \\
\hline Retail & 20 \\
\hline Service & 30 \\
\hline Total & 55 \\
\hline
\end{tabular}

Data for the study was collected through direct observation of the businesses involved and by monitoring websites, telephone messages, and social media sites. None of the data collected in the survey was of a confidential nature and small business owners declined questions explaining their decisions. Finally, 100 random customers were surveyed by the researchers to determine if they were confused by their States' use of essential versus non-essential classifications. Seventy-eight percent of the customers surveyed indicated that they were confused by the classifications and $58 \%$ stated their confusion affected their initial buying decisions. 


\section{RESEARCH RESULTS}

An analysis of the data collected by from the study revealed the following three themes:

1. Small business owners liberally interrupted state mandated classifications of essential versus non-essential business.

2. Communication techniques used by small business to convey their businesses status were inconsistent and confusing.

3. Small business owners underutilized social media platforms to communicate their status under state mandated stay at home orders.

\section{Theme 1}

The first theme to emerge from the data revealed that small business owners inconsistently applied the classifications of essential versus non-essential as defined by state mandated stay at home orders to their business situations. Of the fifty-five businesses involved in the survey, thirty-two or $58.2 \%$ of the businesses fell into the non-essential classification. Fifteen or $46.9 \%$ of these non-essential businesses remained open during the stay at home order period. Seven of the non-essential businesses fell into the retail sector. Four or $57.1 \%$ of the non-essential retail businesses remaining opened sold specialty foods that fell outside of the state's definitions of essential "Stores that sell groceries and medicine, Food, beverage, licensed marijuana production, and agriculture, and Restaurants for consumption off-premises classifications". These small businesses changed their product mix and business models to increase their appearance of being classified essential and remained open. For example, some non-essential retail businesses added either carry-out or curbside service. This group of non-essential small businesses chose to remain open and went unchallenged by local authorities. The remaining three small businesses were small one-person traditional retailers (TABLE 4) that remained open by appointment. Both manufacturing small businesses involved in this study, classified as non-essential, remained closed as directed.

TABLE 4

NON-ESSENTIAL SMALL BUSINESSES INVOLVED IN THE STUDY

\begin{tabular}{|c|c|c|c|c|}
\hline $\begin{array}{c}\text { Business } \\
\text { Classification }\end{array}$ & Number & Closed & Open & \% Open \\
\hline Manufacturing & 2 & 2 & 0 & 0.0 \\
\hline Retail & 12 & 5 & 7 & 58.3 \\
\hline Service & 18 & 10 & 8 & 44.4 \\
\hline Total & 32 & 17 & 15 & 46.9 \\
\hline
\end{tabular}

Eighteen or $56.2 \%$ of the non-essential businesses involved in the study were service in nature. Eight or $44.4 \%$ of these businesses remained open during the state mandated stay at home order. All of these businesses fell outside any approved essential business classification. Half of these businesses were personal service in nature and should have remained closed. The remaining four service small business involved in the study argued that they fell into in to either the "Home-based care and services" or "Manufacture, distribution, and supply chain for critical products and industries" classifications remaining open during the stay-at-home period. None of these business owners decisions to remain open we challenged by local authorities.

Twenty-three or $41.8 \%$ of the small businesses involved in the study fell into the essential classification. Sixteen or $69.6 \%$ of those businesses remained open during their state's stay at home order (TABLE 5). The three small essential manufacturing firms involved in the study, closely followed their state's stay-athome orders. Six or $60 \%$ of the ten essential retail businesses remained open during the stay at home order. All of the essential retail businesses fell into the either the "Stores that sell groceries and medicine or Restaurants for consumption off premises" classifications. Of the four essential retail business remaining 
closed, one informed customers of the need to take extra precautions during the pandemic and three closed permanently due to poor sales. All of the small businesses classified as essential service involved in the study remained open during the state mandated stay at home order.

TABLE 5

ESSENTIAL SMALL BUSINESSES INVOLVED IN THE STUDY

\begin{tabular}{|c|c|c|c|c|}
\hline $\begin{array}{c}\text { Business } \\
\text { Classification }\end{array}$ & Number & Closed & Open & \% Open \\
\hline Manufacturing & 3 & 3 & 0 & 0.0 \\
\hline Retail & 10 & 4 & 6 & 60.0 \\
\hline Service & 10 & 0 & 10 & 100.0 \\
\hline Total & 23 & 7 & 16 & 69.6 \\
\hline
\end{tabular}

The classifications of essential and non-essential businesses were an attempt by state officials to bring about an orderly and safe managerial process throughout the stay at home period. Many states, especially in small communities, left enforcement issues to local authorities. Thus, provided local officials and small business owners the opportunely to interpret these definitions to their benefit resulting in inconsistent and confusing crisis management (Rodriquez, 2020).

\section{Theme 2}

Adding to the confusion of the stay-at-home orders were the inconsistent techniques used by business owners to communicate their status to customers (TABLE 6). At beginning of the crisis, nine or $16.4 \%$ of the fifty-five small businesses involved in the study simply placed a sign on the door of their establishment communicating their status during the stay at home order. All but two of the signs were written on $8.5 \times 11$ inch printer paper with messages too small to read from the street or side walk. Eleven or $20 \%$ of the businesses left a message on their telephone recorders conveying the status of their business during the stay at home order. Nine businesses or $81.8 \%$ used telephone messages in conjunction with some other communication media. Two businesses used telephone messages as their sole communication technique. Four or $7.3 \%$ of the small businesses only placed a message on their websites while two or $3.6 \%$ used social media as their sole communication technique. Nearly half or $49.1 \%$ of the small businesses involved in the study did nothing to communicate their status to customers relying instead on local media outlets to communicate State mandates relating to stay at home orders.

TABLE 6

TECHNIQUES USED BY SMALL BUSINESS OWNERS TO COMMUNICATE THEIR STAY-AT-HOME STATUS

\begin{tabular}{|l|c|c|}
\hline \multicolumn{1}{|c|}{ Communication Technique } & Number & $\%$ \\
\hline Sign on Door & 9 & 16.4 \\
\hline Telephone Message Only & 2 & 3.6 \\
\hline Message on Website Only & 4 & 7.3 \\
\hline Social Media Platform Only & 2 & 3.6 \\
\hline Multiple Techniques & 11 & 20.0 \\
\hline No communication Total & 27 & 49.1 \\
\hline \multicolumn{2}{|}{$\quad 55$} & 100.0 \\
\hline
\end{tabular}

Confusion over the status of businesses continued to plague customers as states phased-in their reopening plans. Thirteen or $23.6 \%$ of the small businesses only placed signs on their doors communicating their compliance with their State's phased-in reopening plan. Communication techniques such as messages 
on telephone recorders, websites, and social media platforms went essentially unused as parts of the business owners' reopening plans (TABLE 7). Forty businesses or $72.8 \%$ of the small businesses involved in the study chose not communicate their reopening plans to customers deferring to local media for general message communication. Lacking specific reopening information, customer remained confused noting that many of the businesses involved altered their open hours and/or operations plans to comply with social distancing regulations (Edwards, 2020).

TABLE 7

TECHNIQUES USED BY SMALL BUSINESS OWNERS TO COMMUNICATE THEIR RELEASE FROM STAY-AT-HOME STATUS

\begin{tabular}{|l|c|c|}
\hline \multicolumn{1}{|c|}{ Communication Technique } & Number & $\%$ \\
\hline Sign on Door & 13 & 23.6 \\
\hline Telephone Message Only & 0 & 0.0 \\
\hline Message on Website Only & 0 & 0.0 \\
\hline Social Media Platform Only & 1 & 1.8 \\
\hline Multiple Techniques & 1 & 1.8 \\
\hline No communication Total & 40 & 72.8 \\
\hline \multicolumn{2}{|c|}{} \\
\hline
\end{tabular}

\section{Theme 3}

One unanticipated study finding was the underutilization of websites and social media platforms as a means to communicate business status by the small business owners involved in the study. The majority or $83.6 \%$ of the small businesses involved in the study had a Website and $78.2 \%$ had an active Facebook page (TABLE 8). In addition, $45.5 \%$ of these businesses had an active presence in either Twitter or Instagram. The study revealed that only eight or $17.4 \%$ of the businesses used to their websites to communicate critical COVID 19 information to their customers. Despite the popularity and convenience of social media, only four or $9.3 \%$ of the businesses used their platforms as a communication device.

TABLE 8

\section{SOCIAL MEDIA AVAILABLE FOR USE BY SMALL BUSINESS OWNERS TO COMMUNICATE STATUS DURING STAY-AT-HOME ORDER}

\begin{tabular}{|c|c|c|c|c|}
\hline $\begin{array}{c}\text { Social Media } \\
\text { Platform }\end{array}$ & $\begin{array}{c}\text { Number of } \\
\text { Available } \\
\text { Businesses }\end{array}$ & $\%$ & $\begin{array}{c}\text { Number Used for } \\
\text { COVID 19 } \\
\text { Communication }\end{array}$ & $\%$ \\
\hline Website & 46 & 83.6 & 8 & 17.4 \\
\hline Facebook & 43 & 78.2 & 4 & 9.3 \\
\hline Other & 25 & 45.5 & 0 & 0.0 \\
\hline
\end{tabular}

\section{CONCLUSION}

The first conclusion from the study is that many small businesses classified as nonessential found a way to remain open during the stay at home orders. Of the nonessential retail businesses involved in the study, $58.3 \%$ found a way to stay open. In addition, $44.4 \%$ of the nonessential service businesses remained open. The vague language of the stay at home orders and their inconsistent enforcement by municipalities aided the action of these business owners. The confusion as to business status increased confusion among customers. Customer confusion was compounded by the fact that some small businesses involved in the study and classified as essential chose to remain closed. 
The second finding from the study was that many small owners failed their customers through ineffective communication. Approximately half or of the business owners chose not to communicate their status as the stay at home orders went into effect and $72.8 \%$ of these same owners chose not to communicate their status as they were released from the order. These business owners relied on State issued public service announcements to communicate their business status. Twenty percent of the business owners involved in the study chose to employ multiple methods of communication such a telephone messages, or posts on websites and social media platforms to communicate their initial shutdown status, however, only $1.8 \%$ of these same owners chose to communicate their status upon release their stay-at-home orders. Not surprisingly, many business owners relied on door signs as their sole method of communication to customers. At the imposition of the stay at home orders, $16.4 \%$ of the survey participants hung a door sign to communicate their status and upon release from the orders $23.6 \%$ of the owners used a door sign as the sole means of communication.

The third finding from the study was how little digital communication was used during the stay at home order period. The majority of the business or $83.6 \%$ involved in the study had websites yet only $17.4 \%$ of the business owners chose to use the sites as effective communication devices. Social media had a strong presence among the small businesses surveyed. Active Facebook accounts were found for $78.2 \%$ of these businesses. For the duration of the stay at home period, only $9.3 \%$ of the accounts were used to communicate with customers. In addition to Facebook, $45.5 \%$ of the small businesses survey were active of other social media platforms such as Instagram and Twitter. None of these other platforms were used by business owners to communicate with customers during the stay at home orders.

\section{LIMITATIONS AND FUTURE RESEARCH DIRECTIONS}

This study was limited to small businesses operating in a Midwestern community with a population less than 20,000. These results may not be representative of all similar sized municipalities. Further, the majority of survey participants were small businesses employing less than ten employees. This analysis was intended to give a general understanding of the confusion facing businesses owns and customers during state mandated Stay-at-home orders. Therefore, it is dependent upon the judgment of the reader and specific settings of the region as to the appropriateness of its finding's. Future study can be directed to focus on narrower areas of concern and analysis to validate the results presented in this study.

\section{REFERENCES}

Acton, A. (2020, April 30). Director's Stay Safe Ohio Order. Retrieved May 18, 2020, from https://coronavirus.ohio.gov/static/publicorders/Directors-Stay-Safe-Ohio-Order.pdf

Bose, N., \& Fares, M. (2020, March). What is essential? Retailers face confusion over government rules on store closings. Retrieved May 18, 2020, from https:/www.reuters.com/article/us-healthcoronavirus-usa-retail/what-is-essential-retailers-face-confusion-over-government-rules-on-storeclosings-idUSKBN2153L6

Clement, J. (2020, May 19). Percentage of U.S. population who currently use any social media from 2008 to 2019. Retrieved May 19, 2020, from https://www.statista.com/statistics/273476/percentage-ofus-population-with-a-social-network-profile/

Coleman, M. (2020, May 8). US jobs report USA to provide clearer data on economic cost: Live updates. Retrieved May 16, 2020, from https://upnewsinfo.com/2020/05/08/us-jobs-report-usa-to-provideclearer-data-on-economic-cost-live-updates/

Conerly, B. (2020, March 24). What Is Essential Business in A COVID-19 Shelter-In-Place Order? Retrieved May 17, 2020, from https://www.forbes.com/sites/billconerly/2020/03/24/what-isessential-business-in-a-covid-19-shelter-in-place-order/\#352e2ad5467b 
Dore, J. (2019, January 30). Small Businesses Generate 44 Percent Of U.S. Economic Activity Release No. 19-1 ADV. Retrieved May 18, 2020, from https://advocacy.sba.gov/2019/01/30/smallbusinesses-generate-44-percent-of-u-s-economic-activity/

Edwards, S. (2020, April 23). Consumer confusion: What business reopening plans mean for Hamilton County and Chattanooga. Retrieved May 23, 2020, from

https://newschanne19.com/news/local/consumer-confusion-what-business-reopening-plans-meanfor-hamilton-county-and-chattanooga

Giese, C. (2020, March 4). How Many Small Businesses Are in the U.S.? (And Other Employment Stats). Retrieved March 17, 2020, from https://www.fundera.com/blog/small-business-employment-andgrowth-statistics

Guttmann, A. (2019, May 13). Social media marketing penetration in the U.S. 2013-2019. Retrieved May 19, 2020, from https://www.statista.com/statistics/203513/usage-trands-of-social-mediaplatforms-in-marketing/

Huddleston, T. (2020, March 23). How small business owners are coping with COVID-19 pandemic: 'It was my civic duty to be a part of the solution'. Retrieved May 18, 2020, from https://www.cnbc.com/2020/03/23/how-small-businesses-across-us-are-coping-with-covid-19pandemic.html

Kaufer, K. (2020, January 6). Podcast Advertising Trend Predictions For 2020. Retrieved March 19, 2020, from https://www.forbes.com/sites/forbesagencycouncil/2020/01/06/podcast-advertisingtrend-predictions-for-2020/\#4af6dd696a14

LaMarco, N. (2019, January15). How Much Does Television Advertising Really Cost? Retrieved March 19, 2020, from https://smallbusiness.chron.com/much-television-advertising-really-cost58718.html

Lauckner, S. (2020, April 18). How Many Small Businesses Are in the U.S.? (And Other Employment Stats). Retrieved May 18, 2020, from https://www.fundera.com/blog/small-businessemployment-and-growth-statistics

Long, H. (2020, April 16). U.S. now has 22 million unemployed, wiping out a decade of job gains. Retrieved May 18, 2020, from https://www.washingtonpost.com/business/2020/04/16/unemployment-claims-coronavirus/

Mack, J. (2020, March 25). Michigan employers want to comply with stay-at-home order, but need more clarity, business leaders say. Retrieved June 10, 2020, from https://www.mlive.com/publicinterest/2020/03/michigan-employers-want-to-comply-with-stay-at-home-order-but-need-moreclarity-business-leaders-say.html

Marketing Charts. (2019, April 23). AM/FM Radio Listeners Keep Tuning In. Retrieved March 19, 2020, from https://www.marketingcharts.com/cross-media-and-traditional/radio-traditional-and-crosschannel-108187

Nestor, M., \& Thompson, J. (2019, February 12). The Importance of Telephone Communication in Business. Retrieved May 19, 2020, from https://smallbusiness.chron.com/importance-telephonecommunication-business-22150.html

NFIB. (2020, March 23). New NFIB study on the impact of COVID-19 on small business. Retrieved May 16, 2020, from https://www.nfib.com/content/news/connecticut/new-nfib-study-on-the-impact-ofcovid-19-on-small-business-3/

Pieser, J. (2019, March 6). Podcast Growth Is Popping in the U.S., Survey Shows. Retrieved April 10, 2020, from https://www.nytimes.com/2019/03/06/business/media/podcast-growth.html

Rahman, O. (2017, June 1). The Psychology of Good Signage and How to Make It Work for Your Business. Retrieved May 19, 2020, from https://www.entrepreneur.com/article/295082

Ritholtz, B. (2020, March 30). The U.S. Needs Way More Than a Bailout to Recover From Covid-19. Retrieved May 16, 2020, from https:/www.bloomberg.com/news/features/2020-04-30/bailoutisn-t-enough-for-economy-to-recover-from-coronavirus 
Rodriquez, R. (2020, April 21). Essential and non-essential business lists differ in every city. Retrieved May 19, 2020, from https://kmph.com/news/local/essential-and-non-essential-business-listsdiffer-in-every-city

Romero, D. (2020, March 27). In California, confusion over what businesses qualify as 'essential'. Retrieved June 10, 2020, from https://www.nbcnews.com/business/business-news/californiaconfusion-over-what-businesses-qualify-essential-n1170031

Ryan, S. (2020, March 26). Business inquiries to WEDC over Evers' order top 7,000. Retrieved May 18, 2020, from https://www.bizjournals.com/milwaukee/news/2020/03/26/essential-businessinquiries-to-wedc-top-7-000.html

Sandy, J. (2020, April 26). Personal View: Vague definition of 'essential businesses' leads to confusion. Retrieved June 10, 2020, from https://www.crainscleveland.com/opinion/personal-view-vaguedefinition-essential-businesses-leads-confusion

Smale, T. (2019, January 31). How You Can Make Podcasts Your Secret Weapon for Promoting Your Business. Retrieved March 19, 2020, from https://www.entrepreneur.com/article/327151

Stangler, D. (2020, April 24). What Do Recent Surveys Tell Us About Small Business And The Crisis? Retrieved May 16, 2020, from https://www.forbes.com/sites/danestangler/2020/04/24/what-dorecent-surveys-tell-us-about-small-business-and-the-crisis/\#4be $8 \mathrm{~d} 53 \mathrm{~b} 3 \mathrm{~d} 1 \mathrm{f}$

Twiste, L. (2020, April 29). Businesses Battle Through COVID-19. Retrieved May 17, 2020, from $\mathrm{https} / / /$ njbmagazine.com/monthly-articles/businesses-battle-through-covid-19/

U.S. Chamber of Commerce. (2020, April3). Special report on coronavirus and small business. Retrieved May 18, 2020, from https://www.uschamber.com/report/special-report-coronavirus-and-smallbusiness

Wahba, P. (2020, April 20). The retailers that are smartest about shopping tech will finish on top after the coronavirus. Retrieved May 19, 2020, from https://fortune.com/2020/04/20/coronavirusretail-industry-ecommerce-online-shopping-brick-and-mortar-covid-19/ 